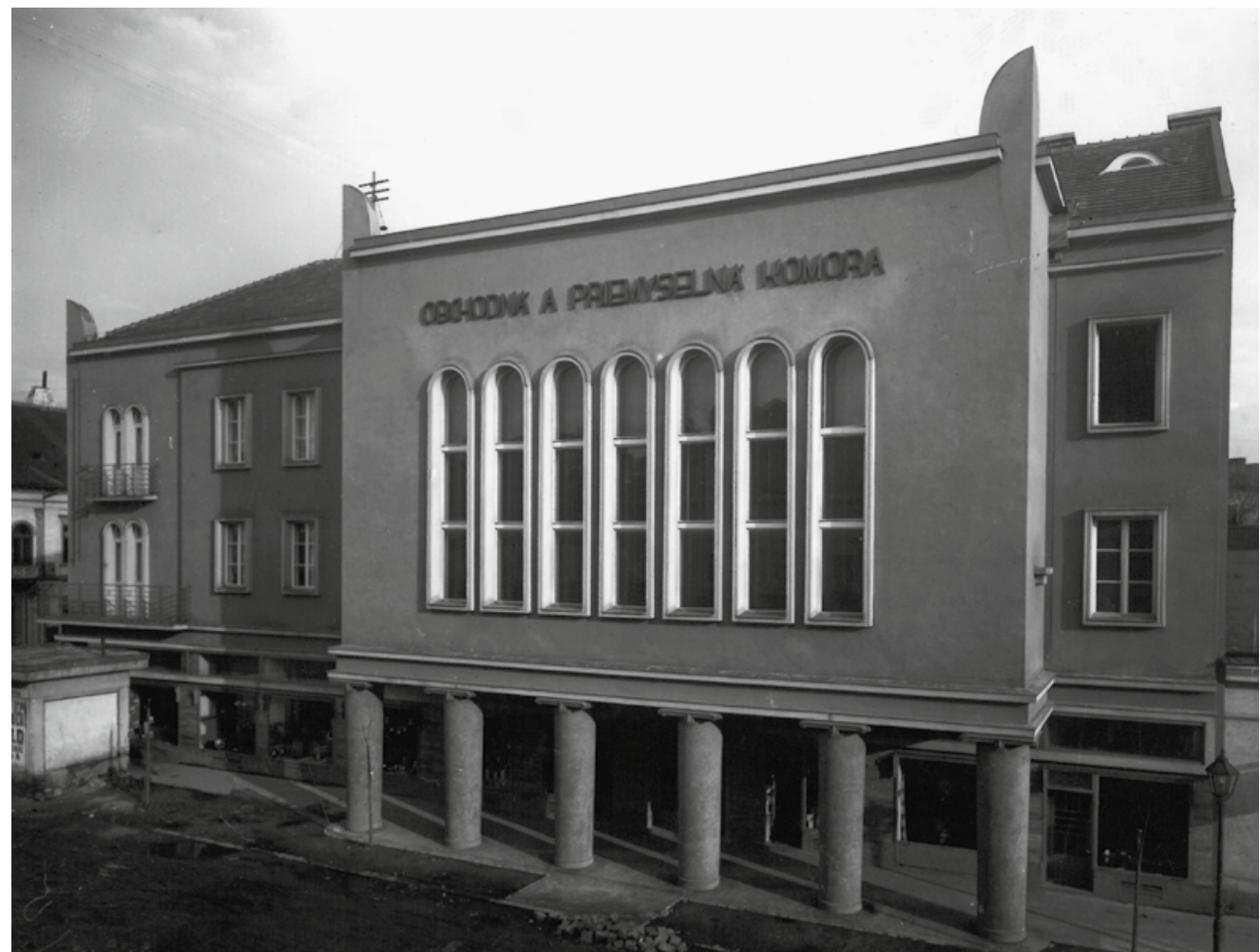

LUUDOVÍT OELSCHLÄGER, THE CHAMBER OF COMMERCE AND INDUSTRY IN KOŠICE, BAČíKOVA 2, AROUND 1930

L'UDOVÍT OELSCHLÄGER OBCHODNÁ A PRIEMYSELNÁ KOMORA V KOŠICIACH, BAČÍKOVA 2, OKOLO 1930

Source Zdroj: The East Slovak Museum Košice, Collection of Historic Photographs, Györy \& Boros photo studio

\title{
The Chamber of Commerce and Industry in Košice
}

\section{Obchodná a priemyselná komora v Košiciach}

\section{Adriana Priatková}

https://doi.org/10.31577/archandurb.2021.55.1-2.7

Históriu novostavby Obchodnej a priemyselnej komory (OPK) v Košiciach - originálneho reprezentanta architektonického dedičstva košickej moderny, do istej miery naplnil už predchádzajúci archívny výskum autorky. Ten postupne priniesol nielen chýbajúcu dobovú projektovú a fotografickú dokumentáciu samotnej komorovej budovy, poznanie jej pôvodných exteriérových, no najmä interiérových kvalít, riešenia dispozícií a účelnej prevádzky, ale aj kvality zlatožltých travertínových obkladov vstupných priestorov, keramických dlažieb či umelého kameňa v kontexte schodísk. Zachovali sa ich pôvodné, pre tento priestor dizajnované kovové zábradlia, a tiež bohatá štuková výtvarná výzdoba stropov s originálnym geometrickým dizajnom. Tie sú pravdepodobne dielom skvelého spolupracovníka autora projektu OPK architekta Oelschlägera, košického sochára, kamenára a štukatéra Júliusa Krištófa. Výskum tejto zaujímavej osobnosti Košíc ešte nie je ukončený, no je viac ako pravdepodobné, že architektovej tvorbe najmä dvadsiatych rokov 20. storočia, punc výtvarnej originálnosti dodával práve on. Bohaté variácie umeleckého dotvorenia exteriérov, no najmä interiérov, aj v Európe v stále aktuálnom štýle art deco, obohacujú diela architekta tak v Košiciach (Ortodoxná synagóga a škola, Kino Fórum, Hasičská kasáreň, bytový dom na Mäsiarskej 9, budova OPK a mnohé iné), v Tornali (Mestský úrad, Evanjelický kostol), Michalovciach (Kino a Mestský úrad), Tatranskej Polianke (Sanatórium Dr. Ghura - prístavba), v Ružbachoch (Biely dom), Nových Zámkoch a inde, ako aj na Ukrajine, niekdajšej Podkarpatskej Rusi. Dotvárajú napríklad dizajn židovskej školy a spoločenského domu, tiež polyfunkčného kina a knižnice v Užhorode, ale aj Obecného domu v Sevluši - teraz Vinohradovo, Obecného domu v Svaljave, či kina v Mukačeve.

Žial', z budovy OPK zmizol dobový mobiliár, aj originálne interiérové svietidlá, ktoré sú zachytené na dobových fotografiách košického ateliéru Győry o Boros tesne po dostavbe.

Novým prínosom bolo aj nájdenie časti projektovej dokumentácie novostavby moderného nárožného bytového domu pre úradníkov penzijného fondu komory (1937). A to jednak kvôli uvedomeniu si rozsahu pôsobnosti tejto unikátnej medzivojnovej inštitúcie, ktorá do siedmich rokov 
od dokončenia novostavby samotnej budovy OPK dokázala zrealizovat' moderné bývanie pre vyše dvadsat' rodín svojich zamestnancov, ale aj pre autora projektu bytového domu. Oslovený bol opät' architekt Oelschläger, ktorý invenčné riešenie tentoraz zákazky v kontexte bývania, s odkazmi na kompozičné riešenie presvetlenia priestoru nad vstupom židovskej školy v Užhorode - vertikálnym pásom ukončeným kruhovým oknom (1926), použil v Košiciach nad vstupom bytového domu, ale v opačnom garde. Hladkú asymetrickú uličnú fasádu, s akcentom nárožných okien, doplñajú francúzske okná a tmavohnedý keramický obklad sokla a vstupných portálov. Realizátorom moderného bytového domu v závere historického centra mesta, tak ako aj novej budovy OPK, bol opät domáci stavitel' Hugo Kaboš.

$\mathrm{V}$ priebehu necelého roka po dostavbe bytového domu pre zamestnancov komory, sa vedenie košickej OPK angažuje aj na príprave jubilejnej výstavy k 2o. výročiu ČsR. Na architektonickej sútaži na budúcu podobu hlavných pavilónov Výstavy východu 1938, ktoré po jej ukončení mali slúžit novej vysokej škole technickej v Košiciach, sa zúčastňuje aj architekt Oelschläger. Nájdenie sútažných projektov na hlavné pavilóny výstavy, medzi ktorými bol aj spoločný projekt architektov Oelschlägera a Friedmanna, prekvapilo. Hoci autorom vítazného návrhu hlavného pavilónu výstavy „Československý štát" v štýle pragmatického funkcionalizmu bol český architekt Rudolf Brebta, zaujímavé riešenie priniesli aj Košičania. Pri návrhu vstupného priečelia hlavného pavilónu výstavy sa inšpirovali výtvarným riešením hlavného priečelia ústredného pavilónu svetovej výstavy v Bruseli z roku 1935.

The Chamber of Commerce and Industry (Obchodná a Priemyselná Komora in Slovak; hereinafter OPK) in Košice was established in 1850 as one of the most prominent such institutions in Austro-Hungary, operating across eight regions and 56 districts encompassing a population of 1.5 million. As the territory of the Hapsburg Monarchy was divided into 60 chamber regions, the OPK in Košice was one of seventeen such regional chambers in the Kingdom of Hungary. Initially, the Chamber in Košice operated from two leased offices in the building of the Košice Savings Bank at Hlavná 4 and was formed with the primary aim of supporting the development of local commerce and industry and overcoming specific business problems which existed within the district. Typically, the management of the Chamber was drawn from leading figures in the economic life of the city and district who could use their influence in critical decisions, such as the extension of the railway network to Košice and later to Kysak and Prešov, the urban development of the city and its gasification and electrification, and the introduction of vocational education, in which it played a pioneering role in Hungary. OPKs were mandatory organizations covering all sectors of commerce, crafts and industry and were funded through specific surcharges on direct earnings taxes. ${ }^{1}$

The Košice Chamber continued its activities after the establishment of the Czechoslovak Republic. The Ministry for Slovak Administration issued Regulation 139/1919 which amended the territories of individual OPKs in line with the borders of the new state, with the Košice Chamber now incorporating the regions of Spiš, Šariš and Užhorod, the area of the Zemplín and Abov-Turňa counties and the province of Subcarpathian Rus. ${ }^{2}$

The OPK sought to raise the economic level and contribute to improving production and commerce in the region, both through collaboration with local businessmen and in its capacity as an advisory body to all levels of public administration, including those at the highest level. Among its main tasks was the compilation of reports for the Ministry on the economic conditions in the region, cultivating sales opportunities for local producers and promoting infrastructural development. One of the most important activities was its cooperation in transport, post and communication, and the OPK was heavily involved in the construction of new railways and the nationalization of private railways and advocated for revisions to postal and telegraphic rates.

The OPK also organized numerous trade fairs which, in addition to their social and educational benefit, were mainly focused on promoting local firms and producers with the aim of gaining new sales opportunities. Conditions for organizing trade fairs and public expositions only re-emerged after the end of the war and the subsequent consolidation of political and commercial relationships. This was particularly the case for Slovakia, which had become part of the newly established Czechoslovak Republic in 1918 following the collapse of the Austro-Hungarian Empire. Further complicating the post-war situation in Slovakia was the need to undergo a complex phase of territorial integration to match the internationally decreed borders, especially the border with Hungary, which suffered considerable destruction during the Hungarian-Czechoslovak War from April to June 1919. Slovakia was also forced to cope with the long-term negative consequences of its separation from Hungary, including the loss of traditional markets, the disadvantageous north-south orientation of the railway network and the shortages of qualified personnel. Economic ties between the less developed, overwhelmingly agrarian Slovakia and the more advanced economies of the Czech lands formed only gradually and were not without difficulties. ${ }^{3}$ Business conditions in the Czech lands were significantly more favourable, as reflected in the annual national Commercial Exposition held there between 1920 and 1938.

With considerable support from the Košice OPK, the first post-war Commerce and Industry Exposition was held in Košice in September 1922, and Sub-Carpathian Rus's first trade 


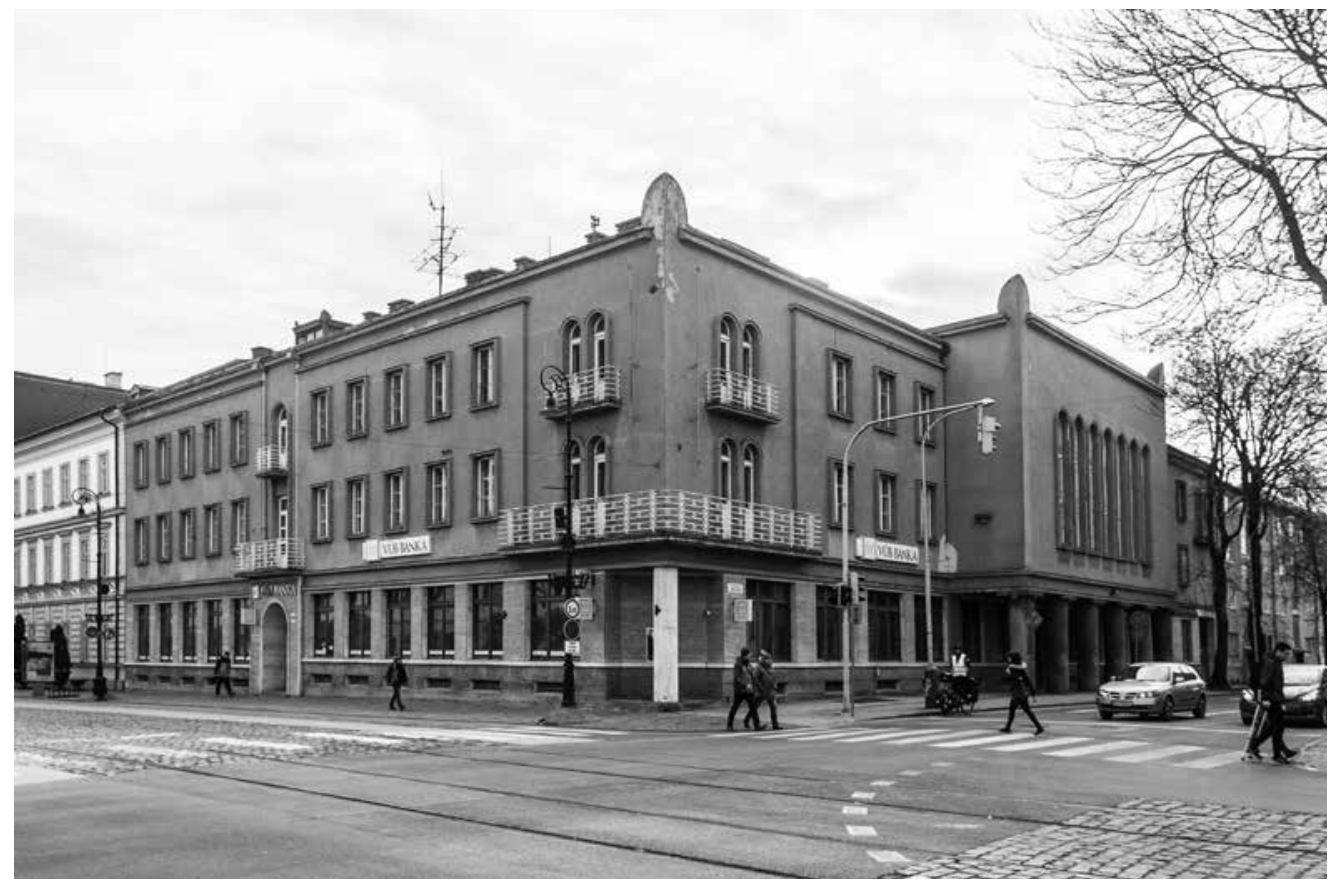

LUUDOVÍT OELSCHLÄGER, THE CHAMBER OF COMMERCE AND INDUSTRY IN KOŠICE, HLAVNÁ 112 BAČíKOVA 2

L'UDOVÍT OELSCHLÄGER, BUDOVA OBCHODNEJ A PRIEMYSELNEJ KOMORY $V$ KOŠICIACH, HLAVNÁ 112 - BAČÍKOVA 2

Source Zdroj: Photo by Miroslava Liakhovych

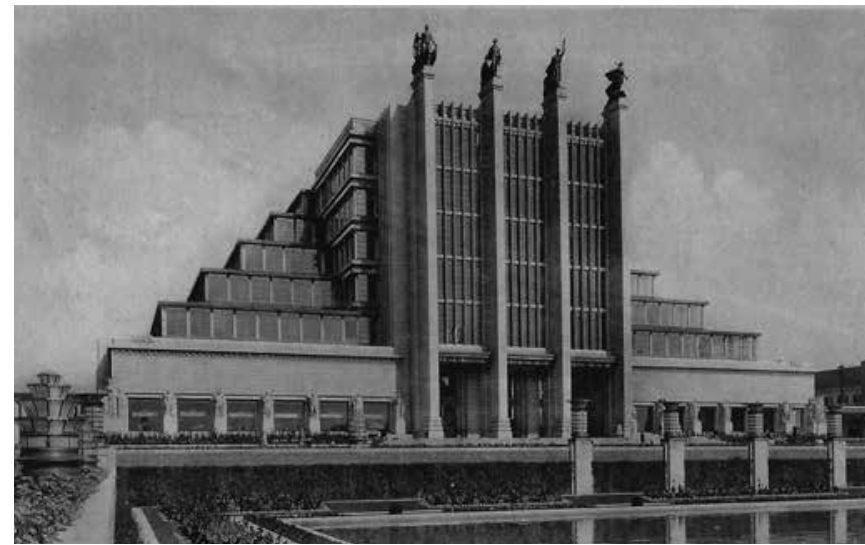

THE CENTRAL PAVILION OF THE BRUSSELS INTERNATIONAL EXPOSITION IN 1935

ÚSTREDNÝ PAVILÓN

MEDZINÁRODNEJ VÝSTAVY

VBRUSELI Z ROKU 1935

Source Zdroj: On Wikimedia Commons. Also: KOMORA, Pavol: Hospodárske a všeobecné výstavy 1842 - 1940

[Trade and Public Expositions in Slovakia 1918 - 1938], p. 223

exhibition was held in Uzhhorod and its first commercial fair in Mukachevo, both in 1927. Of the 19 exhibitions held in Košice in the inter-war years, the Košice OPK devoted the greatest attention to the preparation and organization of the Exposition of the East which was held in 1938 to commemorate the twentieth anniversary of the establishment of the Czechoslovak Republic. Work on the preparation of the exposition was undertaken by the exhibition office under its director, the Czech architect Václav Roštlapil $(1901-1979)^{4}$ and also by Associate Professor Jiří Kroha $(1893-1974)^{5}$ who had worked on many exhibitions both in Czechoslovakia and abroad, including the Jubilee Exhibition in Brno in 1928 and the Construction and Housing Exhibition in Brno in 1933. The overall concept of the exposition and the plan of the exhibition area were drawn up by Kroha's close collaborator, the Czech architect Miloslav Kopriva (1894 - 1963). ${ }^{6}$ The aim of the project was to construct a modern exhibition area including four permanent pavilions which could be converted for later use as a planned technical college. The winner of the competition for the design of the main "Czechoslovak State" pavilion was a pragmatic functionalist proposal by Rudolf Brebta $(1885-1953)^{7}$, a Czech architect who was active in inter-war Košice. An interesting alternative design for the main pavilion was the unrealized proposal by the Košice architects L'udovít Oelschläger $(1886-1984)^{8}$ and Ernest Friedmann $(1899-\text { ? })^{9}$, in which the main façade used an art deco approach forming a reduced parallel to the central pavilion of the Brussels International Exposition in $1935 .{ }^{10}$ Oelschläger and Friedmann's proposal for entrances to the "Engineering" and "Agriculture" pavilions are an example of the mutual professional respect between the architects and Brebta, with Brebta's rational constructivism merging with Oelschläger's creativity in the final design. The fourth pavilion, "Rural Slovakia", which compositionally closed the space in front of the main pavilion on the western side, was designed by the Košice architect Vojtech Šipoš $\left(1888\right.$ - 1969). ${ }^{11}$ The organisation of the interiors of the main pavilions and the exhibits was planned by students of the School of Applied Arts in Prague, with the participation of Associate Professor Pavel Janák $(1882-1956)^{12}$ and the Czech architect Karel Koželka 


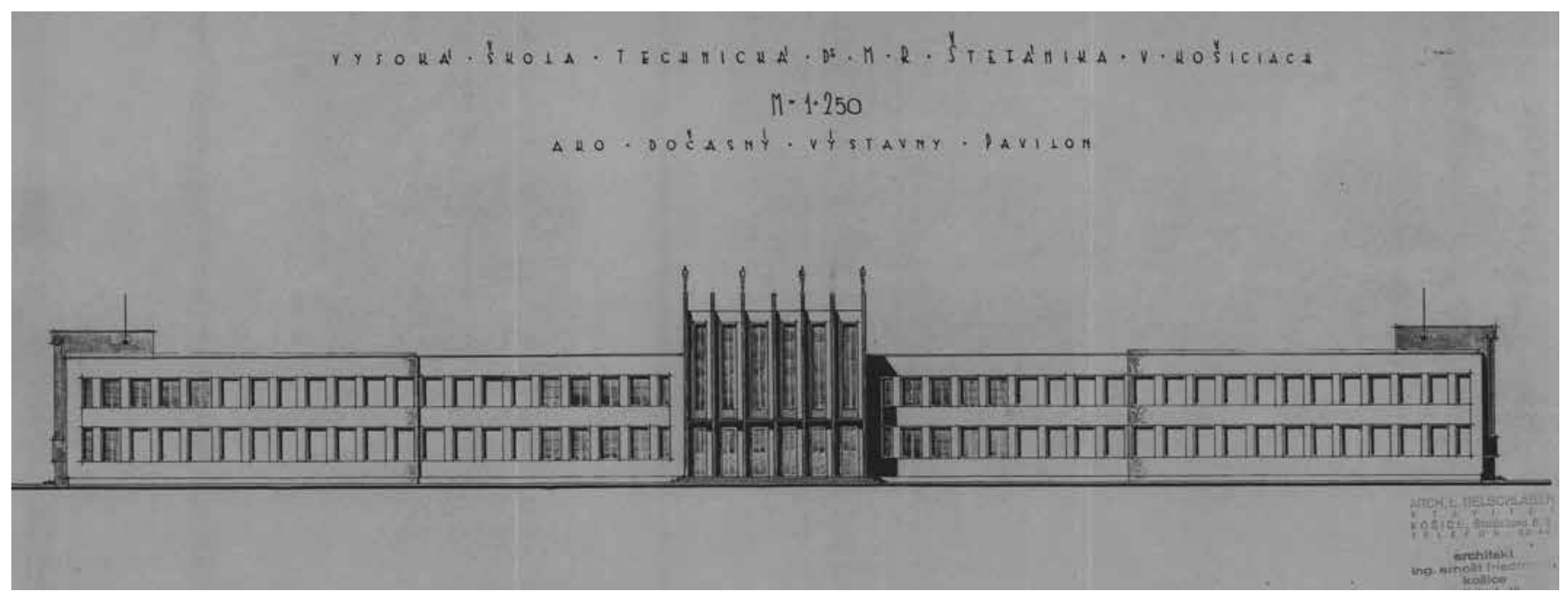

ARCHITECTS L'UDOVÍT

OELSCHLÄGER AND ERNEST

FRIEDMANN: THE DR. M. R. ŠTEFÁNIK

TECHNICAL UNIVERSITY IN

KOŠICE, 1937

ARCHITEKTIL'UDOVÍT

OELSCHLÄGER A ERNEST

FRIEDMANN, VYSOKÁ ŠKOLA

TECHNICKÁ, DR. M. R. ŠTEFÁNIKA

$\checkmark \mathrm{KOŠICIACH}, 1937$

Source Zdroj: Archive of the Town of Košice
ARCHITECT EDUARD ŽÁČEK: THE TRADE VOCATIONAL SCHOOL ARCHITEKT EDUARD ŽÁČEK ODBORNÁ ŽIVNOSTENSKÁ ŠKOLA

Source Zdroj: The East Slovak Museum Košice, Collection of Historical Photographs, Győry \& Boros photo studio

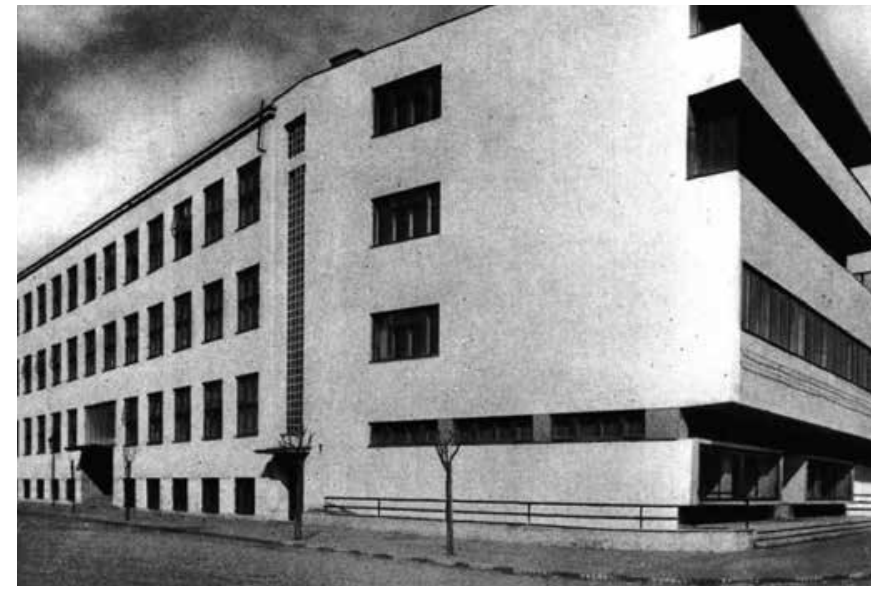

(1909 - 1992). ${ }^{13}$ Held in Košice from July 16th to 31st August 1938, the remarkably successful exposition was praised in commercial and industrial circles. ${ }^{14}$

The Košice OPK was also heavily involved in the development of vocational education. The Chamber sponsored the formation of several vocational schools, for example in Mukachevo $(1925$ - 1926) and in Košice, where the OPK supported the establishment of a pioneering modern vocational school for $800-$ 1000 students. The school building was a functionalist design by the renowned Brno architect Eduard Žáček $\left(1899\right.$ - 1973). ${ }^{15}$

The Chamber organized professional courses and lectures, sponsored scholarships and offered support to pupils of vocational schools, prioritizing the children of poor craftsmen, traders, and merchants. It also donated to various excursions, exhibitions of students work, and also professional courses for teachers with the aim of improving the standard of education. Parallel activities organized by the Slovak Chamber of Commerce and Industry also contributed to the establishment of the first School of Applied Arts in Bratislava in 1928. ${ }^{16}$

\section{Construction of the OPK Building in Košice}

The scope of the activities of the Košice OPK expanded further after the establishment of the Czechoslovak Republic due to the need to prepare its work not only in the official language of Slovak but also in its region's three minority languages - Hungarian, German and Ruthenian. ${ }^{17}$ Between 1919 and 1938, the interests of Slovak commerce remained in a delicate balance with those of Hungarian businessmen operating in east Slovakia and Sub-Carpathian Rus. Due to the broadened agenda, the increased number of employees and the need to further the development of their activities, the rented space in the Košice Savings Bank building no longer sufficed for the needs of the OPK. Therefore, after 1926, the Chamber began to pay serious consideration to the construction of their own premises which would include a library, sample room, lecture halls, classrooms for vocational training for traders and craftsmen and a large reception room for public events. An extensive property on the corner of Hlavná and Tordássyho ulica (now Bačíkova) which was managed by the Womens' Charitable Association for its owners, the firm of Tordassy - Zlinszky, was selected as the site of the new offices. ${ }^{18}$ After a prolonged legal dispute over the foreclosure of the property, an architectural design competition for the new building was prepared and preliminary construction work commenced. ${ }^{19}$ However, none of the submitted proposals fulfilled the conditions of the competition requirements and no winning project was announced, although three second prizes were awarded: 


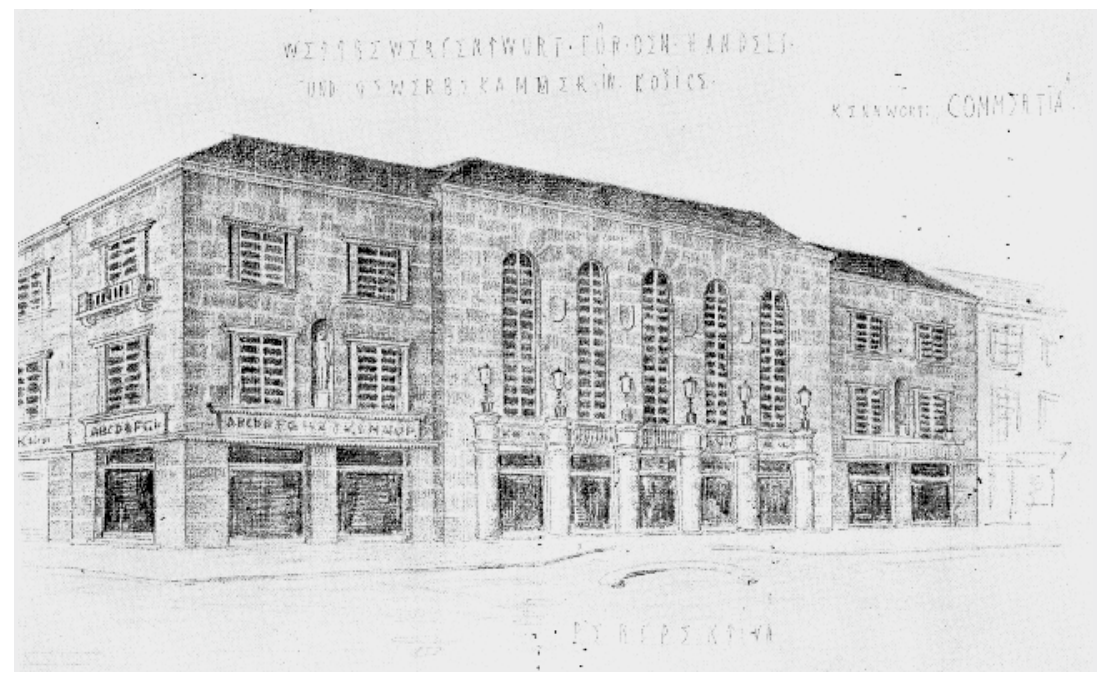

ARCHITECT LUUDOVÍT

OELSCHLÄGER: STUDY OF THE

CHAMBER OF COMMERCE AND

INDUSTRY IN KOŠICE FROM THE

PERIOD PUBLICATION

ARCHITEKT L'UDOVÍT

OELSCHLÄGER, ŠTÚDIA

OBCHODNEJ A PRIEMYSELNEJ

KOMORY V KOŠICIACH Z DOBOVEJ

PUBLIKÁCIE

Source Zdroj: Architekt Ludwig

Oelschläger, Košice. Arbeiten des Dipl.

Ing. Architekt Ludwig Oelschläger,

Košice. Verlag Otto Waldes, Bratislava,

1932

ARCHITECT L'UDOVÍT

OELSCHLÄGER, THE CHAMBER OF COMMERCE AND INDUSTRY IN KOŠICE 1929.

ARCHITEKT L'UDOVÍT

OELSCHLÄGER, OBCHODNÁ

A PRIEMYSELNÁ KOMORA

$\checkmark$ KOŠICIACH, 1929

Source Zdroj: Archives of the Town of Košice

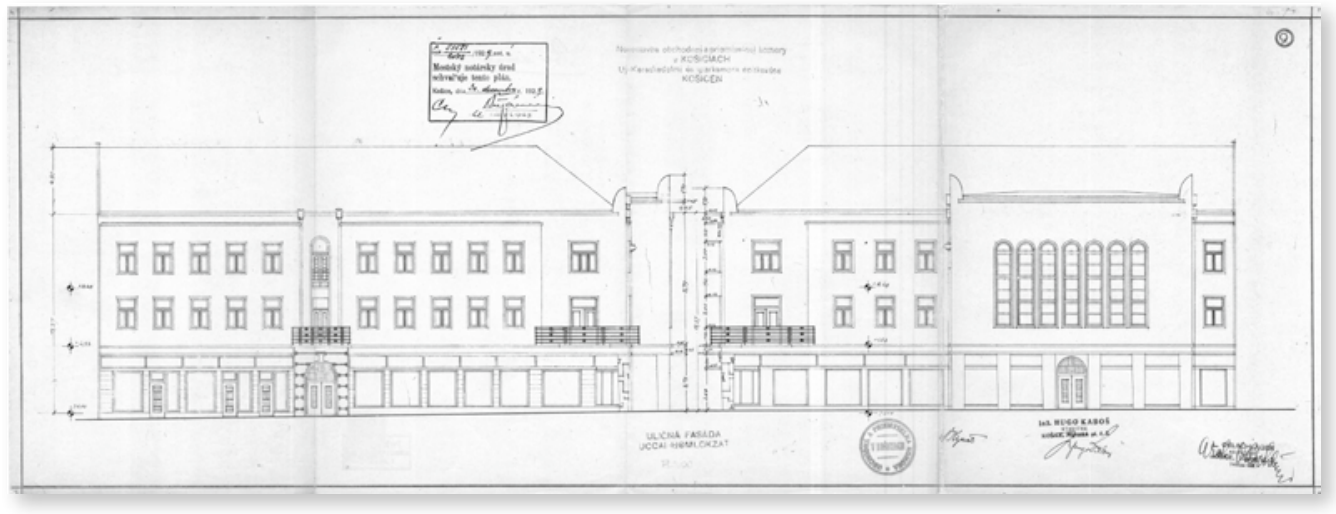

to the Czech architect Rudolf Brebta, the renowned Bratislava architect Milan Michal Harminc $(1869-1964)$ and the Košice architect L'udovít Oelschläger. ${ }^{20}$

The final design for the new OPK building in Košice was completed in 1929. ${ }^{21}$ Its preparation was entrusted to the ambitious 33-year-old Oelschläger, who had already successfully designed several large scale public buildings in the city. ${ }^{22}$ A regular participant in architectural competitions, Oelschläger had won prestigious commissions not only in his hometown but also in other towns in Slovakia and Sub-Carpathian Rus.. ${ }^{23}$ After graduating from the Technical University of Budapest in 1921 and completing a two-year study tour of Europe, he gained work experience at the Budapest architecture studio of Géza Bogdánfy ${ }^{24}$ and Gedeon Gerlóczy $\left(1895\right.$ - 1975). ${ }^{25}$ In 1924 he returned to Košice, collaborating with the architect Zoltán Géza Boskó ${ }^{26}$ until 1929, later establishing his own architectural firm in the house of his father, the iron magnate L'udovít Oelschläger Sr. While the management of the Košice OPK granted Oelschläger the commission for the design of the new building on the basis of his earlier work, the presence on the competition jury of his elder brother Štefan, a co-owner of the prosperous family iron business, may also have contributed to his success. ${ }^{27}$ The modern Košice OPK building was constructed in 1930 by the local construction firm of Ing. Hugo Kaboš with an investment of 2,700,00o Kčs. ${ }^{28}$
An outline of the situation of the structure, floor plans of the ground and upper floors and also a perspective view of an early variant of the front façade of the building in a somewhat inelegant classical approach can be found in a collection of the architect's work which was published in the 1930 . $^{29}$ The perspective view of the corner of the proposed building with the title "Handels und Gewerbekammer in Košice" and the motto "COMMERTIA" presented in the collection was likely a part of the architectural drawings that Oelschläger submitted to the architectural competition. The plan of the three-storey OPK building was arranged in an "L"-shaped structure, with both wings of the building almost equal in length. Clients would enter the main entrance on Hlavná ulica, while the staff entrance was placed on Bačíkova. ${ }^{30}$ The publication from the 1930 also includes a depiction of the planned extension of the building towards Bačíkova and Mäsiarska, which would give the building a "U"-shaped form. ${ }^{31}$

The axially symmetrical design of the entrance façade featured a centre section which projected slightly onto the street. Above the extensive glazed shopfronts of the commercial units on the ground floor, tall windows set into a shallow avant-corps illuminated a two-level hall within. The ceremonial monumentality of the exposed façade of the multifunctional building was emphasized by a series of classical, downward-tapering half-columns attached to the window pillars. This initial design 


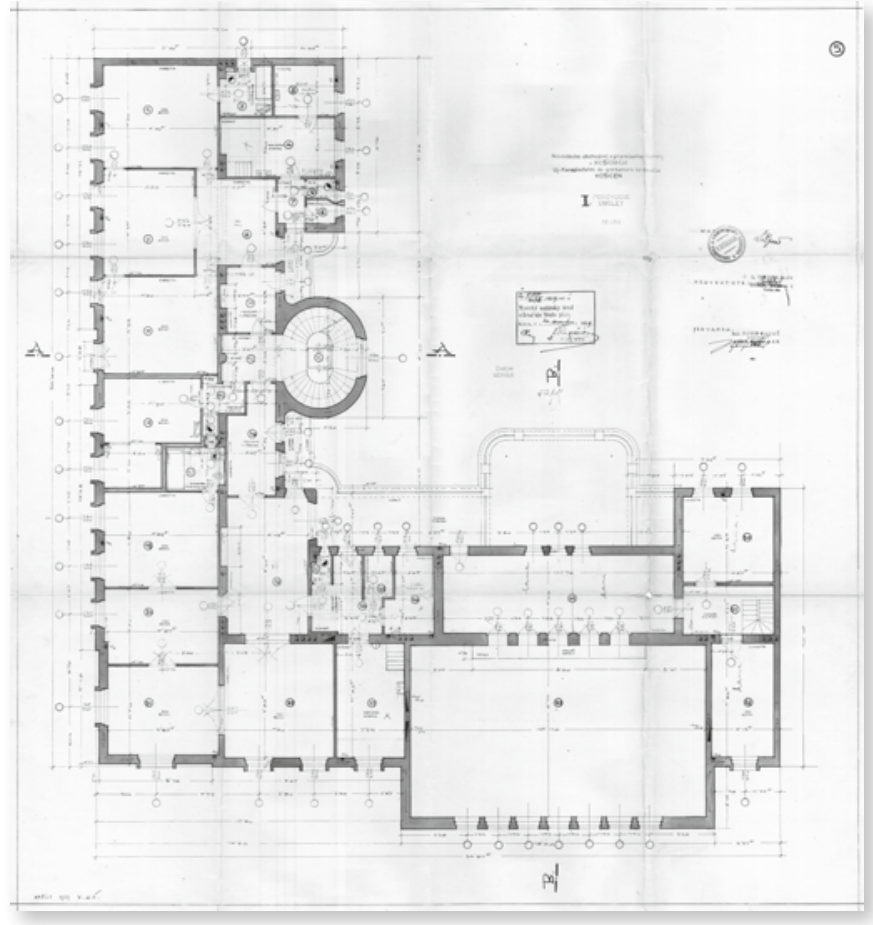

LUDOVÍT OELSCHLÄGER,

THE CHAMBER OF COMMERCE

AND INDUSTRY IN KOŠICE, 1929.

SECOND FLOOR PLAN

L'UDOVÍT OELSCHLÄGER

OBCHODNÁ A PRIEMYSELNÁ

KOMORA V KOŠICIACH, 1929

PÔDORYS 2. NADZEMNÉHO

PODLAŽIA

Source Zdroj: Archives of the Town

of Košice

underwent subsequent changes and clashed to some degree with the later floor plan of the building from 1929 in which the avantcorps was extended into the street, with the columns positioned awkwardly below. Lamps mounted vertically on columns, a design feature found in many of Oelschläger's works, bring the rhythm of the first floor to a close. This initial concept of the design shown in the 1932 publication was complemented by two semi-circular niches with statues positioned between the windows on the sides of the avant-corps.

Although the basic conception of the OPK building was apparent from the terms outlined in the architectural design competition, the path to the final design of the structure was by no means straightforward. The requirements called for a modern multi-functional building which should be self-financing but also provide autonomous and efficient operational space for a modern institution. In order to avoid any disruption to the activities of the building's various functions, the ground floor was allocated to commercial units and related storerooms, each provided with separate entrances. The management and administrative offices of the OPK were to be located on the first floor, together with a multipurpose two-level hall and necessary adjoining spaces. The main entrance to the OPK building was located on Tordassyho ulica (now Bačíkova) through an elegant and spacious lobby faced with pale gold travertine from Bešeňová near Ružomberok and an imposing staircase. The

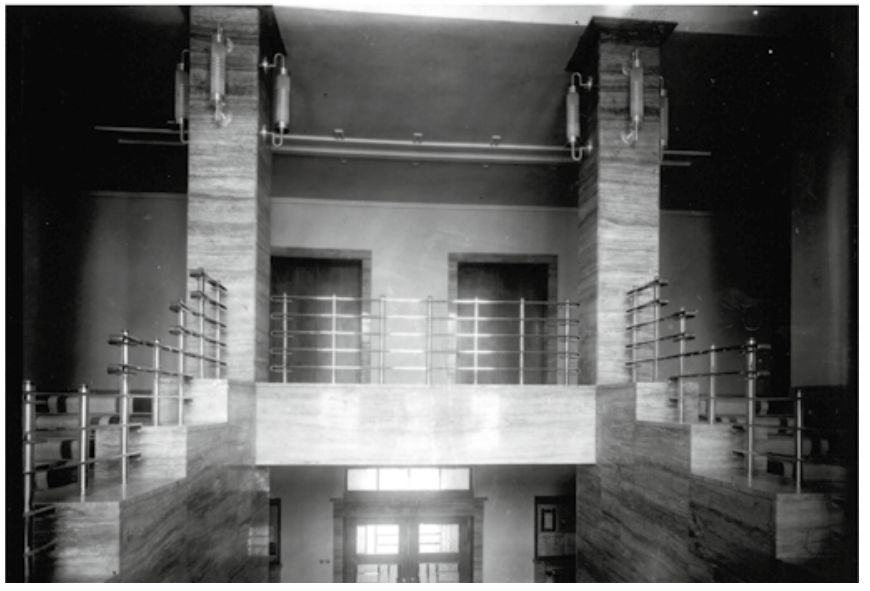

LUDOVÍT OELSCHLÄGER, THE CHAMBER OF COMMERCE AND INDUSTRY IN KOŠICE, THE MAIN ENTRANCE HALL AROUND 1930

LUUDOVÍT OELSCHLÄGER, OBCHODNÁ PRIEMYSELNÁ KOMORA V KOŠICIACH, HLAVNÁ VSTUPNÁ HALA, OKOLO 1930

Source Zdroj: The East Slovak Museum Košice, Collection of historical photographs, The Győry \& Boros photo studio

lobby led to large and small reception halls, the main boardroom, the offices of the director and secretary, an archive and several offices. The entrance on Hlavná led to a smaller staircase which served the OPK offices facing the main street and a series of apartments located on the second floor. These comfortable and spacious apartments were intended for the use of Chamber officials, although the arrangement of these 5, 4, 3, and single roomed apartments was changed over the course of construction. A third staircase variant gave access to the lecture halls and classrooms on the second floor. Part of the complex was also rented to various firms for commercial purposes.

The ongoing process of developing and fine-tuning of the original design, and the gradual evolution of the layout and form of the building towards a more modern approach, is apparent in the project documentation from 1928 and 1929. ${ }^{32}$ Plans in 1:100 scale from October 1928 show that the pillars on the ground floor still had a quadrilateral cross-section, while the design of the Tordassyho (Bačíkova) façade is uninventive, with only the rounded corners worthy of interest. In the 1:50 scale plans from October 1929, however, the conceptual design was now finalized. The original published sketch of a classical symmetrical façade of the entrance on Bačíkova had been reworked into a more modern and elegant form: the Renaissance-influenced original competition proposal transformed into a more abstract Purist and monumentalist design. The main entrance, covered by a massive projecting avant-corps consisting of the first and second floors of the building supported by six substantial columns which unconventionally taper downwards, is on the north side of the building. The elegantly designed artificial stone columns with finely contoured bases and gently inclined capitals feature details rendered in plasterwork. The corner on the first floor had 


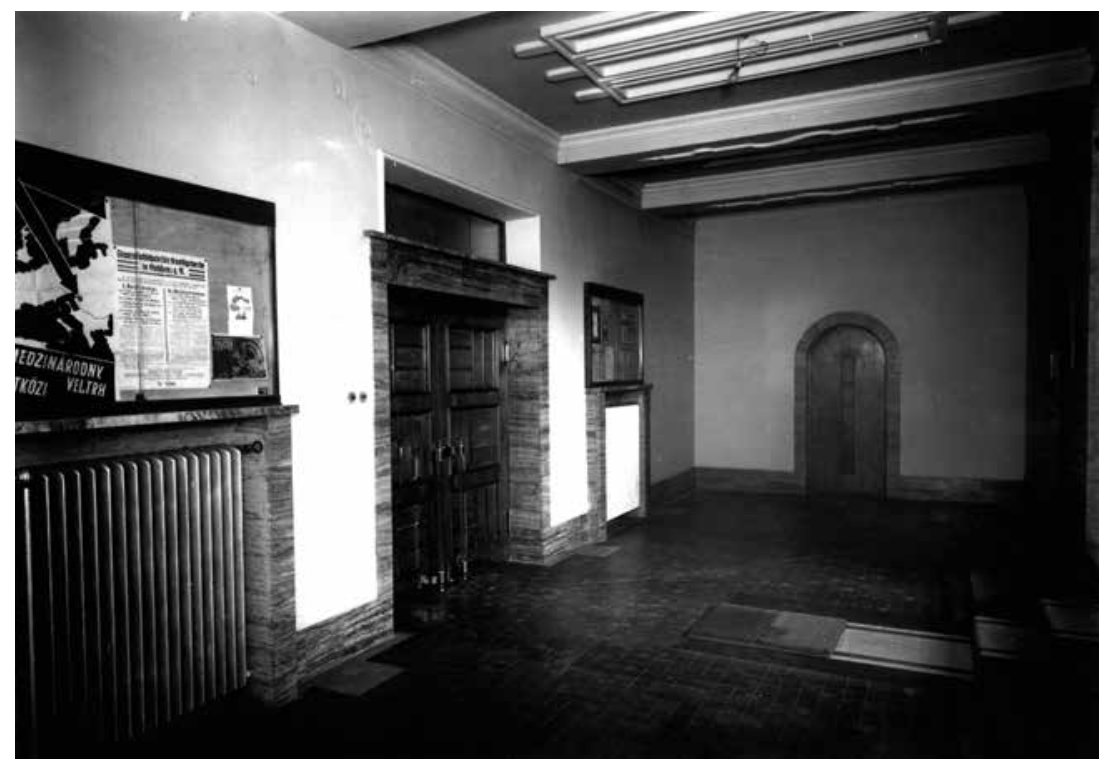

L'UDOVÍT OELSCHLÄGER,

OBCHODNÁ A PRIEMYSELNÁ

KOMORA V KOŠICIACH, HLAVNÁ

VSTUPNÁ HALA

L'UDOVIIT OELSCHLÄGER

OBCHODNÁ PRIEMYSELNÁ

KOMORA V KOŠICIACH, HLAVNÁ

VSTUPNÁ HALA

Source Zdroj: The East Slovak Museum Košice, Collection of historical photographs, The Györy \& Boros photo studio reverted to its original form of the proposal found in the 1932 publication, in which the ground floor section displays a convex curvature. The line of intersection between the two street façades continues through a dominant smooth column in Spiš travertine without base or capital which embellishes the entire ground floor. This accentuation of the first floor in the corner of a city block forming a conclusion to the built-up area in the northern part of a historic city centre was also adopted almost a decade later in another location by the Bratislava architect Alexander Skutecký. ${ }^{33}$

A similar approach in urban setting and form can be seen in the design of the Jewish school and community centre in Uzhhorod $^{34}$ and the community centre in Sevluš (modern day Vynohradiv in Ukraine). This arrangement of a projecting avantcorps with tall windows illuminating a large two-level hall for meetings and events appears in several of Oelschläger's works from the first half of the 2oth century, while the original form of the columns tapering downwards can be found in the entrance to his Kino Fórum (Slovan) from 1926 - 1927 in Košice. It is highly probable that Oelschläger collaborated with the noted Košice sculptor, stonemason and stucco mason Július Krištóf $(1878-\text { ? })^{35}$ in the design of the OPK building's columns and the original stylized geometric ornamentation with variations on art deco motifs, as was the case with many of the architect's famous works in Slovakia, Ukraine and Hungary.

The resultant layout and form of the OPK building is a logical development from Oelschläger's formal vocabulary from the late 1920s, in which the architect plays with classical motifs in his own distinctly modern style in combination with art deco detail. Evidently, after his return from the study tour of Europe which he undertook immediately completing his studies in $\mathrm{Bu}$ dapest, he began to respond in his work to contemporary architectural events, such as the International Exhibition of Modern Decorative and Industrial Arts held in Paris in 1925. At the same time, Oelschläger also followed architectural trends in the newly formed Czechoslovakia, where, in addition to other interesting figures, the extraordinarily creative Slovenian architect Jože Plečnik was active in this period at Prague Castle. Coincidentally, Plečnik was entrusted with the reconstruction of the Ljubljana Chamber of Commerce, Trade and Industry from 1925 to $1927.3^{36}$ Plečnik was inspired by ancient architecture, ${ }^{37}$ a period that held a strong appeal for Oelschläger, who would himself go on to play with the motifs of early Aegean culture not only in the main entrance of the Košice OPK building, but also in his other designs in Sub-Carpathian Rus.

After the completion of the Košice OPK building and its opening in October 1930, the Chamber operated continuously in the premises until December 1948. At the close of 1937, the Chamber implemented a further element of the ambitious original plans for the development of the property through the construction of a modern rental apartment building on the northwest corner of Mäsiarska and Bačíkova ulica, ${ }^{38}$ again designed by Oelschläger. The extension was funded by the OPK Administrators' Pension Fund for whom the three-storey residential building with central heating was completed in less than nine months by the Košice construction firm of Ing. Hugo Kaboš. ${ }^{39}$

\section{Conclusion}

The far-reaching international events of 1938 had a direct impact on the operations of the OPK in Košice. Following the Vienna Arbitration, the city, together with parts of south Slovakia and Sub-Carpathian Rus, was conceded to Horthy's Hungary. Given that the Chamber would be forced to work on behalf of its members in both the Slovak and Hungarian parts of its territory, there was a clear need to divide the institution. On the basis of a mutual agreement, the Slovak section was relocated to Prešov, where the Slovak and Czech officials began working immediately in three offices in a town house under difficult circumstances. ${ }^{40}$

The Chamber employees returned to Košice after the end of World War II and the restoration of the Czechoslovak Republic in 1945, with the OPK resuming its activities across the entirety 


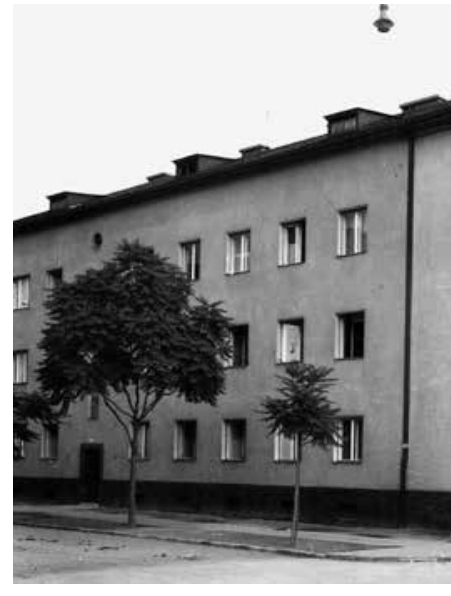

LUUDOVÍT OELSCHLÄGER,

REALISATION ING. HUGO KABOŠ,

THE TENEMENT HOUSE OF

THE CHAMBER OF COMMERCE

AND INDUSTRY IN KOŠICE,

BAČíKOVA 8-MÄSIARSKA 61,63

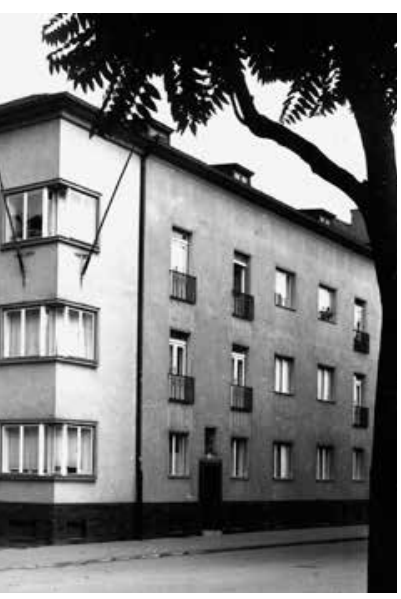

L'UDOVÍT OELSCHLÄGER, REALIZÁCIA ING. HUGO KABOŠ, NÁJOMNÝ DOM OBCHODNEJ A PRIEMYSELNEJ KOMORY VKOŠICIACH, BAČÍKOVA 8 MÄSIARSKA 61, 63

Source Zdroj: The East Slovak Museum Košice, Collection of historical photographs, The Győry \& Boros photo studio

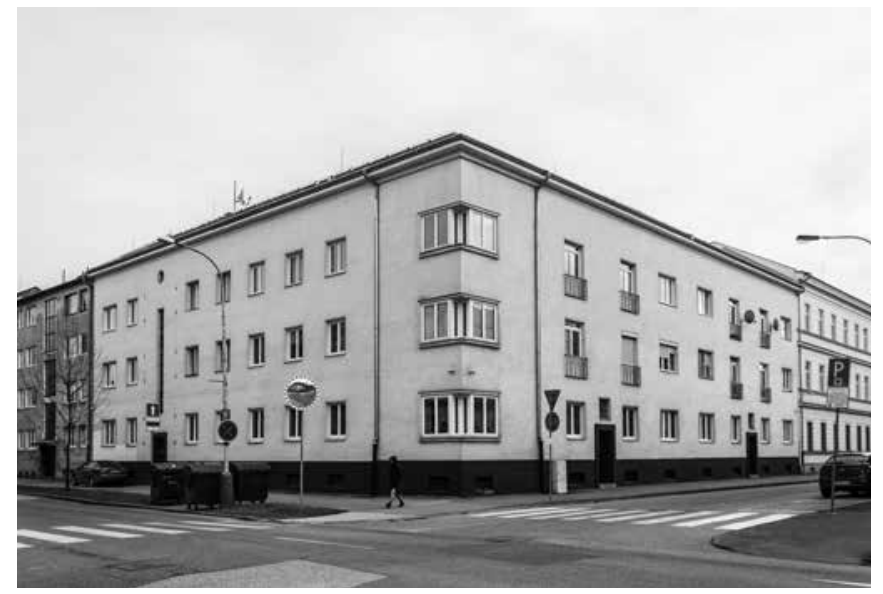

LUDOVÍT OELSCHLÄGER, REALISATION ING. HUGO KABOŠ, THE TENEMENT HOUSE OF THE CHAMBER OF COMMERCE ANDINDUSTRY IN KOŠICE
1 PYTLÍK, Pavol, 2010. Kapitola prvá roky monarchie $(1850-1818)$, p. 9. In: Kapitoly z dejin Obchodnej a priemyselnej komory $v$ Košiciach $(1850-2010)$. [Chapters on the History of the Chamber of Commerce and Industry in Košice] Slovenská obchodná a priemyselná komora. Compiled by Ing. L. Korotnoky.

2 KOROTNOKY, L'udovít, 2010: Obchodná a priemyselná komora v Košiciach. In.: OBCHOD - PRIEMYSEL HOSPODÁRSTVO. Mesačník Slovenskej obchodnej a priemyselnej komory. 19(7), pp. $6-7$.

3 KOMORA, Pavol, 2016. Hospodárske a všeobecné výstavy 1842 - 1940. V. Hos podárske a všeobecné výstavy na Slovensku v rokoch 1919 - 1938, Bratislava: Slovenské národné múzeum - Historické múzeum, p. 241.

4 ROŠTLAPIL, Václav, 2011. Architect, city planner, graphic designer and publicist. Studied at the Czech Technical University from 1919 to 1924. From: VALDHANSOVÁ, Lucie. Brněnský architektonický manual. Brno: Dům umění.

5 Júri Kroha. Studied at the Czech Technical University in Prague, architect, artist, sculptor, set designer, lecturer, and renowned figure in interwar modernist architecture in Czechoslovakia. In: Prof. Ing. arch. Jiř Kroha. Encyklopedie města Brna. 2019.

6 Miloslav Kopřiva, studied architecture and structural engineering at the Czech Technical University in Prague. From 1921 to 1935 he worked as an independent architect in Brno. He served as head of the engineering
L'UDOVÍT OELSCHLÄGER, REALIZÁCIA ING. HUGO KABOŠ, NÁJOMNÝ DOM OBCHODNEJ A PRIEMYSELNEJ KOMORY $\checkmark \mathrm{KOŠICIACH}$

Source Zdroj Photo by Miroslava Liakhovych, 2019 department of the Košice municipality from 1935 and in 1937 became a full professor in the Department of Structural Engineering at the newly founded Technical University in Košice. See: ŠLACHTA, Štefan, 1988. Miloslav Kopŕiva. Project. 318(6), pp. $38-40$.

7 BREBTA, Rudolf. Studied at Czech Technical University in Prague. Until 1923 he worked at the construction firm of Adolf Lipscher a Co, moving to Košice for the period 1922 to 1938 He designed many interwar buildings in the city mainly in collaboration with the Ing. Al. Novák construction firm. See: GAŠPAR, Ján, BLAŠKOVÁ, Eleonóra and MIHOKOVA, Mária, 2014. Lexikón Košičanov. 1848 - 1938. A - I., Košice, pp. 146, 147.

8, L'udovít (Ludwig) Oelschläger and Lajos Öry (1896 - 1984). For more, see: PRIATKOVÁ, Adriana and PÁSZTOR, Peter, 2012. Architekt. építész. architect Oelschläger - Öry. Agentúra SAŠA Košice, s. r. o.

9 FRIEDMANN, Ernest, 1930. A renowned Košice architect whose professional work in the city began immediately after his graduation from the German Technical University in Prague in 1930. Details about his graduation were identified by Veronika Szeghy-Gayer, PhD in the newspaper Prágai Magyar Hírlap. 9(285), p. 11.

10 AMK, TO, SF, Letná ulica Projektová dokumentácia k Výstave východu. + Dobová pohladnica On Wikimedia Commons. Also: KOMORA, Pavol,. Hospodárske a všeobecné výstavy 1842 - 1940. p. 223. 
11 Vojtech Šipoš. A renowned and artistically gifted Košice architect, he opened his own architectural studio soon after graduating from the Technical University in Budapest. After World War One he returned to Košice, moving to Vienna from 1923 to 1929 and Berlin from 1929 to 1934. He survived the Holocaust in Budapest and returned to Košice in 1945. Designer of the Masonic Lodge at Tajovského 4 in Košice (1912) and the Orthodox synagogue in Vranov nad Toplou (1921).

12 Pavel Janák. Studied at Czech Technical University in Prague while also attending the studio of Prof. Josef Zítek at the German Technical University. Also studied at the studio of Otto Wagner at the Academy of Fine Arts in Vienna. Professor at the School of Applied Arts in Prague.

13 Ing. arch. Karel Koželka. Interior designer, furniture designer, theoretician and publicist in design.

14 For more on the exposition, see: PRIATKOVÁ, Adriana, 2009. Výstava východu ČSR - Košice 1938. Architektúra \& urbanizmus. 42(3 - 4), pp. 235 - 249. PRIATKOVÁ, Adriana, 2019. AZ 1938 - AS KIÁLLÍTÁS MINT A KASSAI MODERN ÉPÍTÉSZET. In: Változó szerepek, változó városképek Kassa és Miskolc a 20. században. Szerkesztő Tamáska Máté. Észak - Keleti Átjáró Egyesület I Martin Opitz KiadóI Ormos Imre Alapítvány. Budapest, pp. 79 - 99.

15 Košice, corner of Grešákova 1 and Mojmírova Street. For more on the vocational school, see: PRIATKOVÁ, Adriana, 2017. Medzivojnové Košice (1918 - 1938) v kontexte novopostavených školských zariadení na území mesta. Contributions to the ŠVK conference: Vývoj kultúry východného Slovenska. Košice, pp. 186 - 201.

16 DULLA, Matúš and MORAVČÍKOVÁ, Henrieta, 2002. Architektúra Slovenska v 20. storočí. Bratislava: Slovart, DULLA Matúš, PRIATKOVÁ Adriana, 2002 Architektonické diela 2o. storočia na Slovensku. Košice. Architektúra \& urbanizmus 36, (1-2), p. CCXXXI.

17 MIHÓKOVÁ, Mária, Dejiny Obchodnej a priemyselnej komory v Košiciach - 150 rokov. Compiled by: Masaryk, Š. Slovenská obchodná a priemyselná komora. pp. $29,30$.

18 Tordassy - Zlinszky, famous Košice merchant from the 19th century who bequeathed his property to the St. Elizabeth Orphanage. In: PYTLÍK, Pavol, 2011. Kapitola druhá - roky československé (1918 - 1938). In: Kapitoly z dejín Obchodnej a priemyselnej komory v Košiciach 1850 - 2010. Košická regionálna komora SOPK, p. 32.

19 Pytlík, P., 2011, pp. 27, 28.

20 PRIATKOVÁ, Adriana, 2012. History of the building of the Chamber of
Commerce and Industry in the town of Košice. Transactions of the Universities of Košice. 1, pp. $65-71$

21 Construction of the Chamber of Commerce and Industry building in Košice, street facade - Uccai homlokzat. Peč. no. 51581/2072/1929 not. at MNÚ. This plan was approved on zoth December 1929. Hlavná 112 - Bačíkova $2, \mathrm{AMK}, \mathrm{TO}, \mathrm{SF}$.

22 Many important buildings were built in Košice at the end of the 1920 s according to designs by Oelschläger (now listed state cultural monuments), such as the Forum Cinema (1927), the firehouse and barracks (1928) and the Orthodox synagogue and school (in collaboration with Géza Zoltán Bosko, 1927 - 1933). For more, see: Priatková, A. and Pásztor, P., 2012.

23 For example, the Commercial Academy in Mukachevo (1923 - 25), the Jewish school and community centre in Uzhhorod (1925 - 26), the community centre in Vynohradiv (Sevluš) and the Jewish orphanage in Mukachevo (1926). For more, see: Priatková, A. and Pásztor, P., 2012.

24 BOGDÁNFY, Géza and GERLÓCZY, Gedeon épitészek munkái 1922 - 1923. In: Magyar Feltámadás Lexikon (1930).

25 Gedeon Gerlóczy (1895 - 1975) Budapest architect who studied in Munich. For more, see: PÉCZELY, Béla and FERKAI, András, rok: Pest épitészete a két világháború között.

26 Géza Zoltán BOSKÓ. Practising architect from 1920 who collaborated with Oelschläger from 1924 to 1929 before opening his own studio in Budapest.

27 Štefan Oelschläger (1889 - 1977) After graduating from the Grammar School in Košice, he studied at the commercial college in Elberfelde, Germany, gaining professional experience in Graz, Paris, Budapest and Cluj-Napoca. Businessman, co-founder of Flescher $\mathrm{a}$ Schirger in 1915, member of the OPK in Košice. MADARÁSZ, Elemér (ed.), 1940. Magyar politikai és közigazgatási compass. Budapest, p. 606.

28 Oelschläger had regularly worked with Kaboš in the past, for example on the Jewish grammar school in Mukachevo (1924 - 1925), as co-designer and constructor of the Forum cinema (1926 - 1927) and the Orthodox synagogue and school in Košice (in collaboration with Gejza Zoltán Bosko, 1927 - 1933).

29 Architekt Ludwig Oelschläger Košice. Arbeiten des Dipl. Ing. Architekt Ludwig Oelschlager Košice. 1932. Verlag Otto Waldes, Bratislava, Štúrgasse 9a. Waldes Verlag. Comenius University Library, Bratislava, XXI. B. 786.
30 Košice Old Town, Hlavná 112 Bačíkova 2.

31 Bačíkova 8, AMK, TO, SF. The plan was realised in 1938 when a modern apartment building for OPK employees was built on the corner of Bačíkova and Mäsiarska streets by Kaboš according to a design by Oelschläger.

32 AMK, TO, SF, Bačíkova 2. The documentation from 1929 is in two languages, Slovak and Hungarian. The plan in 1:50 scale is dated 11th December 1930.

33 Košice, Hlavná 4, Pribinova 2. Bank and insurance offices. Alexander Skutecký, 1937, 1938 - 1939. Listed state cultural monument.

34 VIRON, Sabina, 2007. Užhorod putování po památných místech židovské minulosti. The 1926 building is shown on p. 14 .

35 For more, see: Priatková, A. and Pásztor, P., 2012.

36 PRELOVŠEK, Damian, 2003. Profánní díla. In: Josip Plečnik, život a dílo. Obchodní, živnostenská a průmyslová komora. 2nd edition, ERA, pp. $247-252$.

37 Although Plečnik initially planned to use the Tuscan order in the project, he was forced to use a Minoan form for the supporting columns when it became apparent during construction that the mid-section between the two wings of the staircase flights was narrower than planned. Prelovšek, D., 2003, p. 250.

38 Mäsiarska 61,63-Bačíkova 8, AMK, TO, SF. "Novostavba činžového domu obchodnej a priemyselnej komory v Košiciach na rohu Továrenskej (Tordássyho) a Mäsiarskej ulice. V Košiciach, 16. februára 1937." Designer: L'. Oelschläger.

39 Bačíkova 8, AMK, TO, SF. Ing. H. Kaboš also supplied the necessary surveying details for the OPK apartment building. Documentation: Application for new assessment of planning use. Construction commenced 1. 4. 1937, completed 15. 12. 1937, (30. 12. 1937 according to the construction journal) and was occupied on 1st January 1938. Stamped: Ing. Hugo Kaboš. Dipl. Inž. in construction for cultural engineering - builder, Košice, Jókaiho (now Jesenského) 8, tel. 2562.

40 PYTLÍK, Pavol, 2011. Kapitola tretia - roky vojnové $(1938$ - 1945). In: Kapitoly z dejin Obchodnej a priemyselnej komory $v$ Košiciach 1850 - 2010. p. 33.
41 In the 1950s, the former OPK building was the seat of the Košice branch of the ŠBČS (Czechoslovak National Bank) and after 1989 of VUB (General Lending Bank). The building is currently empty and dilapidated, while the new owner is attempting to sell the property as an apartment building. 